\title{
Key Abbreviations
}

$\begin{array}{lll}\text { BDM } & \text { Bund Deutscher Mädel } & \text { League of German Girls } \\ \text { DAP } & \text { Deutsche Arbeiterpartei } & \text { German Workers' Party } \\ \text { HJ } & \text { Hitler Jugend } & \text { Hitler Youth } \\ \text { KdF } & \text { Kraft durch Freude } & \text { Strength through Joy } \\ \text { KPD } & \text { Kommunistische Partei } & \text { German Communist Party } \\ & \begin{array}{l}\text { Deutschlands } \\ \text { NSDAP }\end{array} & \text { Nationalsozialistische Deutsche } \\ & \text { Arbeiterpartei } & \text { National Socialist German Workers' } \\ \text { SA } & \text { Sturm Abteilung } & \text { Storm Troopers } \\ \text { SD } & \text { Sicherheitsdienst } & \text { Security Service } \\ \text { SPD } & \text { Sozialdemokratische Partei } & \text { Social Democratic Party of Germany } \\ & \text { Deutschlands } & \\ \text { SS } & \text { Schutzstaffel } & \text { National Socialist Defense Force }\end{array}$


